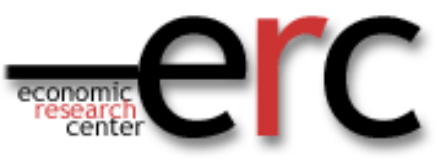

ERC Working Papers in Economics 10/02 October 2010

\title{
Macroeconomic Impact of Remittances on Output Growth: Evidence from Turkey
}

\author{
Aysit Tansel \\ Department of Economics \\ Middle East Technical University \\ Ankara 06531 Turkey \\ Email: atansel@metu.edu.tr \\ Pınar Yaşar \\ State Planning Organization \\ Ankara, Turkey \\ Telephone: 903122946014 \\ Email: pyasar@dpt.gov.tr
}




\title{
MACROECONOMIC IMPACT OF REMITTANCES ON OUTPUT GROWTH: EVIDENCE FROM TURKEY*
}

\author{
by \\ Aysit Tansel $*$ \\ Department of Economics \\ Middle East Technical University \\ 06531 Ankara, Turkey \\ and \\ Institute for Study of Labor (IZA), Bonn, Germany \\ Telephone: 90.312. 2102057 \\ Fax $\quad: 90.312 .2107964$ \\ E-Mail: $\underline{\operatorname{atansel} @ \text { metu.edu.tr }}$ \\ and \\ Pınar Yaşar \\ State Planning Organization \\ Ankara, Turkey \\ Telephone: 90.312. 2946014 \\ E-Mail: pyasar@dpt.gov.tr \\ Revised : June, 2010
}

Key Words: Remittances, Dynamic Model, Remittances-Induced Output Growth.

JEL Codes: F22, F21, C52

\begin{abstract}
This study estimates a Keynesian simultaneous, dynamic macroeconometric model to investigate the impact of remittances on key macro variables such as consumption, investment, imports and income in Turkey. The estimated impact and dynamic multipliers indicate that impact of remittances on consumption, imports and income are all positive and reduce gradually while that on investment wears out in the second year. The impact multiplier for income implies a substantial increase in income due to remittances through the multiplier process. The remittances-induced output growth rate is highest during the early 1970s and the early 1980 s, but negligible during the other years.
\end{abstract}

\footnotetext{
- This article is based on Pınar Yaşar's MA thesis (Yaşar (2005)) prepared under the supervision of Aysıt Tansel at the Department of Economics, Middle East Technical University. An earlier version of this paper is presented at the Turkish Economic Association (TEK) International Conference, 11-13 September, 2006, Ankara. We appreciate able research assistance of Eda Gülsen. We would like to thank two anonymous referees of Migration Letters for valuable comments. Any errors are our own.

- * Corresponding author.
} 


\title{
MACROECONOMIC IMPACT OF REMITTANCES ON OUTPUT GROWTH: EVIDENCE FROM TURKEY
}

\begin{abstract}
This study estimates a Keynesian simultaneous, dynamic macroeconometric model to investigate the impact of remittances on key macro variables such as consumption, investment, imports and output in Turkey. The estimated impact and dynamic multipliers indicate that impact of remittances on consumption, imports and income are all positive and reduce gradually while that on investment wears out in the second year. The impact multiplier for income implies a substantial increase in income due to remittances through the multiplier process. The remittances-induced output growth rate is highest during the early 1970s and the early 1980 s, but negligible during the other years.
\end{abstract}

Key Words: Remittances, Dynamic Model, Output Growth.

JEL Codes: F22, F21, C52 


\section{INTRODUCTION}

Migration flows have become one of the most important features of Western European countries after the Second World War. While Western European countries undertook several measures, such as bilateral agreements to attract foreign workers in order to meet their labour supply shortage, developing countries encouraged the emigration of their workers to overcome domestic economic difficulties. These migration flows benefited both the home and the host countries. The most debated issue about the migration flows from the point of view of the home countries is workers' remittances. Remittances are defined as the money transfers by the migrants residing abroad for more than a year to their home countries. Remittances constituted an important source of external finance for many developing countries. Flows of remittances to developing countries were estimated to be 167 billion dollars in 2005 (World Bank, 2006). Ratha (2003:157) and Adams and Page (2005) draw attention to the fact that workers' remittances constitute the second largest flow of external finance after foreign direct investment and proved to be the least volatile source of foreign exchange earnings for developing countries.

Several studies found that emigration benefited only the migrants and their families by improving their living standards while it did not contribute to the development of Turkey. Studies based on surveys conducted at different times and various regions of the country supported the view that remittances are mostly used for consumption and personal investments in land and housing. Such views are expressed by Paine (1974: 114), Abadan et al. (1975: 411), Gökdere (1978: 226), Martin (1991: 56), Gitmez (1991: 133) and Koç and Onan (2004: 79). A recent study, Yiğit (2005) finds that workers in Germany remit their savings to Turkey with investment purposes rather than consumption purposes. More recently, the weakening of the relation of the second generation Turks with Turkey has led to the use of their savings for investment purposes in Germany.

There have been many studies on the effect of remittances at the household level through surveys in Turkey. To our knowledge, this is the first study on the macroeconomic impact of remittances in a unified framework in Turkey ${ }^{1}$. For this purpose this study estimates

\footnotetext{
${ }^{1}$ The literature on the macro economic impact of the remittances is vast. Stahl and Habib (1991)in South and Southeast Asia, Glytsos (1993) in Greece, Leon-Ledesma and Piracha (2001) in Eastern European transition
} 
a Keynesian dynamic simultaneous equation macroeconometric model for the period 19642003 in order to investigate the impact of remittances on key macroeconomic variables such as private consumption, investment, imports and output in Turkey. The dynamic feature of the model enables examination of the over time behavior of the endogenous variables. The estimated impact and dynamic multipliers indicate that an increase in remittances increases consumption, investment, imports and income. The impact of remittances on these variables reduces gradually except that on investment which wears out within one year. The impact multiplier for income implies a substantial increase in income due to remittances through the multiplier process. The remittances-induced output growth rate is compared with the actual output growth rate. It is found to be highest in the early 1970's and the early 1980's but appears negligible during the other years. This bodes well with diminishing importance of remittances in recent years. Overall, remittances have been a significant positive factor in the economic development and growth of Turkey. The results are put in perspective by intercountry comparisons. The use of the same model facilitates these comparisons.

The rest of the study is organized as follows. Section 2 presents the over time development of remittances in Turkey. Section 3 presents the dynamic, simultaneous, Keynesian macroeconometric model. Estimation of this model and other empirical results are given in Section 4. Finally, the last section provides the concluding remarks. Data sources are given in the Appendix.

countries, Faini (2002) in Korea, Philippines, Ghana and Mexico, Glytsos (2002a and 2002b) in several Mediterranean countries, Burgess and Laksar (2005) in Philippines find a positive impact of remittances on economic growth. On the contrary, Keely and Tran (1989), Chami et al. (2003) and Saca and Caceres (2006) argued for the adverse macroeconomic effects of remittances. Guiliano and Ruiz-Arranz (2005) taking endogeneity into account find a positive effect of remittances on output growth in the developing economies but a null or negative effect at high levels of financial development. Several studies emphasize the contribution of remittances on output growth by expanding loanable funds in the developing economies with a poor financial sector and credit constraints. Aggarwal et al. (2006) examine the impact of remittances on financial sector development of 99 developing countries and conclude that remittances promote financial development by increasing the aggregate level of deposits and credits intermediated by the local banking sector. Dutch Disease as a negative consequence of the remittances is investigated by a number of researchers such as Athukorala (1993), Quibria (1996), Bourdet and Falck (2003), Lucas (2004), Kapur (2004), Acosta et al. (2007) and others. Mishra (2005) shows positive impact of Remittances on private investment. 


\section{WORKERS' REMITTANCES IN TURKEY}

Emigration of Turkish workers to Europe started in the early 1960s. Since then Turkey has exported significant numbers of workers mainly to Western European countries. Germany has received the highest number of emigrants among all other European countries. According to official sources (Turkish Labor Office, 2001), 1476 workers in 1961 and when the highest number moved in 1973, 103793 workers immigrated to Germany. Although the number of emigrating workers declined over time due to economic slack in the host countries as of today there are significant numbers of Turkish migrant workers in Western Europe. In the second half of the 1970s and the 1980s emigration of Turkish workers to the Middle Eastern and North African countries such as Libya, Saudi Arabia and Iraq took place. After 1990, Russia became a major destination country. As of 2001, there were about 2 million Turkish workers abroad and they have generated a significant amount of remittances over time.

The remittances are generally under-reported around the world including Turkey. İçduygu (2006) draws attention to the large informal flows in Turkey and the difficulty in their measurement. This study relies on the official flow of remittances. The sample period stops in 2003 because there is a break in the data after 2003. The Central Bank of the Republic of Turkey reclassified the worker's remittances together with the tourism revenues since 2004. Therefore, the data before and after 2004 are not comparable.

The remittances were around 100 million dollars per annum during the 1964-1969 period and increased to over one billion dollars in the early 1970's. They contributed significantly to closing the trade deficits (Boratav, 2003: 122). The remittances reached a peak of 5.4 billion dollars in 1998 (State Planning Organization, 2003) and declined during the ensuing period. In 1999 the Russian financial crisis and the two earthquakes that destroyed the industrial heartland of the country adversely affected the Turkish economy. The economic and financial crises in November 2000 and February 2001 brought about substantial declines in output and employment. Mauhoud et al. (2006) argues that these crises could be the main reason behind the decline in the inflow of remittances. The crisis erodes the confidence of the migrants to the economy causing them to remit through unofficial channels or simply not to remit at least for investment motives. 
Figure 1 shows the share of remittances in imports, exports and the GDP over the sample period. These shares reached peaks during the 1973-1976 period. The share of remittances in imports was about 55 percent in 1973, their share in exports was over 90 percent in 1975 and their share in GDP was about 4.5 percent in 1974. There have been substantial declines in these shares after 1999. In 2003 the shares in imports and exports declined to less than 10 percent and the share in GDP declined to less than one percent.

Figure 1. The Ratio of Workers' Remittances to Imports, Exports and GDP (1964-2003).

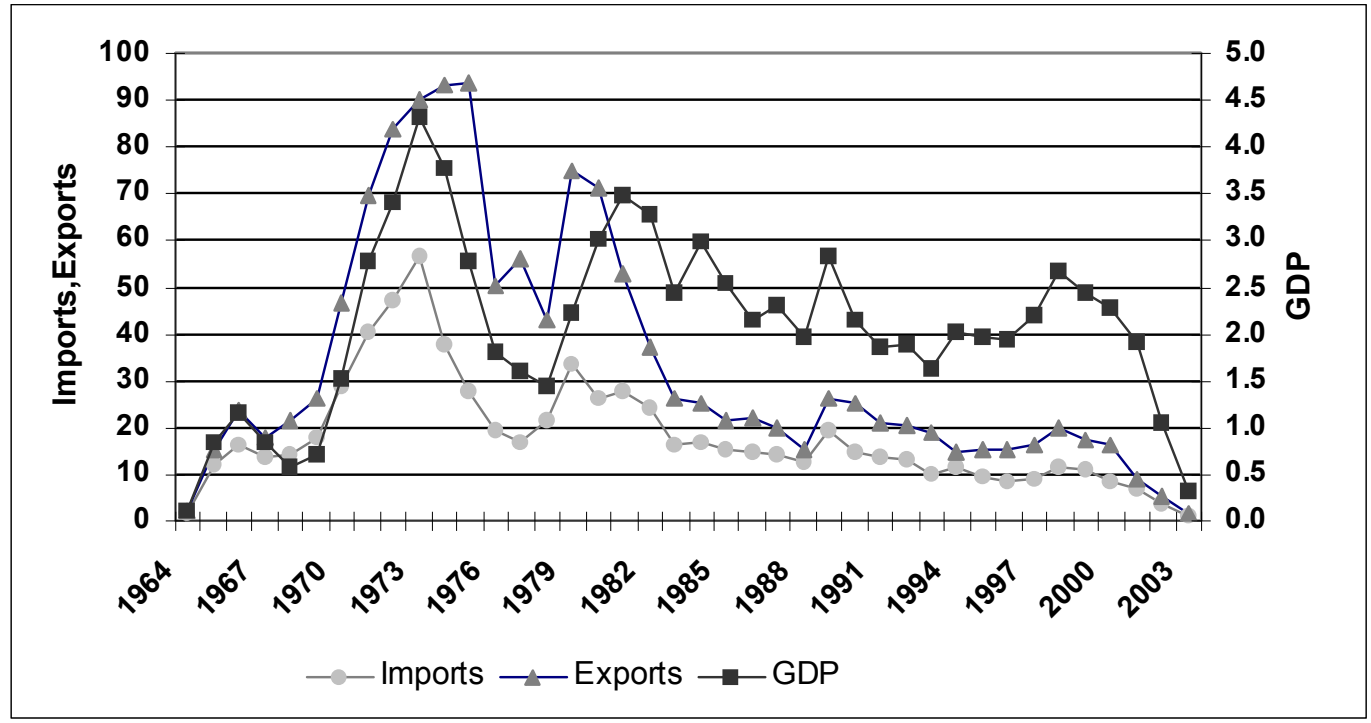

The flow of remittances could be influenced by economic and political crises, and devaluations in the home and host countries as well as by government policies. For instance, Turkish government offered until recently differential exchange rates and special interest rates for foreign currency accounts in order to encourage workers to remit. Similarly, German government passed regulations to encourage return migration when there was a slack in the German economy. Such government policies are summarized in Aydaş et al.(2004) which investigated the determinants of remittances for Turkey ${ }^{2}$. Sayan (2004) and Yiğit (2005) found that remittances respond to the cycles in the Turkish economy but not to the ones in the German economy.

\footnotetext{
2 There are several studies which examine the determinants of remittances, such as Glystos (2002c), who considered the Middle East and North African countries, and Gupta (2005), who considers the evidence from India. Also, Schiopu and Siegfried (2006) analyze the determination of workers' remittance flows from 21 Western European to EU neighboring countries.
} 


\section{THE MODEL}

The model used is a modification of the model due to Glytsos (2002a, 2002b and 2002c). It is a linear, demand oriented, simultaneous equation, dynamic macroeconometric model to determine the effects of workers' remittances on key macroeconomic variables, such as private consumption (C), investment (I), imports (M) and income (Y). There are three behavioral equations, the consumption function, investment function and the import function and a national income identity. The model allows determination of the short-run and long-run effects of an exogenous shock of the remittances on the key macroeconomic variables. The structure of the model is as follows ${ }^{3}$ :

$$
\begin{aligned}
& C_{t}=\alpha_{0}+\alpha_{1} Y_{t}+\alpha_{2} C_{t-1} \\
& I_{t}=\beta_{0}+\beta_{1} Y_{t}+\beta_{2} K_{t-1} \\
& \mathrm{M}_{\mathrm{t}}=\delta_{0}+\delta_{1} \mathrm{Y}_{\mathrm{t}}+\delta_{2} \mathrm{M}_{\mathrm{t}-1} \\
& Y_{t}=C_{t}+G_{t}+I_{t}+E_{t}-M_{t}+R_{t}+S_{t}
\end{aligned}
$$

$\mathbf{Y}$ is the sum of GDP and the remittances (R). $\mathbf{K}$ is the cumulative gross domestic investment. $\mathbf{G}$ is the government consumption expenditure. SD stands for the statistical discrepancy and $\mathbf{t}$ indicates the time. In this model, $\mathbf{C}, \mathbf{I}, \mathbf{M}$ and $\mathbf{Y}$ are endogenous variables. Consumption equation is based on a partial adjustment model $^{4}$. Investment is assumed to be a positive function of income as a proxy of profits and a negative function of lagged capital stock. Imports is a function of the level of income and the lagged imports as an indicator of adaptive expectations. In simultaneous-equations models, ordinary least squares (OLS) estimators are biased and inconsistent because of the correlation between explanatory endogenous variables

\footnotetext{
${ }^{3}$ The distrurbance terms are ignored.

${ }^{4}$ For instance, if the equilibrium relationship between $C$ and $Y$ is defined as $C_{t}^{*}=\beta_{1}+\beta_{2} Y_{t}$ and the dynamic adjustment process is defined by the following partial adjustment model: $\mathrm{dC}_{\mathrm{t}}=\lambda\left(\mathrm{C}_{\mathrm{t}}{ }^{*}-\mathrm{C}_{\mathrm{t}-1}\right)+\mathrm{u}_{\mathrm{t}}$ where $\lambda$ shows the proportion of the deviation adjusted in any one period. When the first equation is substituted into the second one, the following equation is obtained $C_{t}=\theta_{1}+\theta_{2} Y_{t}+\theta_{2} C_{t-1}+u_{t}$ (Stewart and Gill, 1998: 186).
} 
and the stochastic disturbance terms. Two Stage Least Squares (TSLS) method gives estimates that are consistent and efficient (Intriligator, et al., 1996).

\section{EMPIRICAL RESULTS}

There are three empirical evidences presented in this section. First, the model presented in Section 3 is estimated for Turkey using annual data for the period 1964-2003 with TSLS. Second, the estimates are used to obtain impact and dynamic multipliers of endogenous variables with respect to remittances. Third, the multipliers are used to determine the effect of remittances on output growth in Turkey.

Table 1. Two Stage Least Squares Estimates of the Macroeconometric Model.

\begin{tabular}{|c|c|c|c|}
\hline $\begin{array}{l}\text { Explanatory } \\
\text { Variables }\end{array}$ & Consumption & Investment & Imports \\
\hline $\mathrm{Y}$ & $\begin{array}{c}0.350 \\
(4.395)\end{array}$ & $\begin{array}{c}0.329 \\
(3.749) \\
\end{array}$ & $\begin{array}{c}0.160 \\
(3.005)\end{array}$ \\
\hline $\mathrm{C}(-1)$ & $\begin{array}{c}0.428 \\
(3.174) \\
\end{array}$ & - & - \\
\hline $\mathrm{K}(-1)$ & - & $\begin{array}{c}-0.002 \\
(0.144)\end{array}$ & - \\
\hline $\mathrm{M}(-1)$ & - & - & $\begin{array}{c}0.691 \\
(5.598)\end{array}$ \\
\hline D1974 & $\begin{array}{l}-4359.7 \\
(2.395)\end{array}$ & $\begin{array}{l}4765.6 \\
(1.882)\end{array}$ & - \\
\hline D2001 & $\begin{array}{l}-4566.3 \\
(2.041)\end{array}$ & $\begin{array}{l}-8686.8 \\
(2.801) \\
\end{array}$ & - \\
\hline DTotal & - & - & $\begin{array}{l}-3244.6 \\
(-2.392)\end{array}$ \\
\hline Constant & $\begin{array}{l}4552.7 \\
(3.872)\end{array}$ & $\begin{array}{l}-5762.5 \\
(-1.915)\end{array}$ & $\begin{array}{l}-4866.9 \\
(-2.149)\end{array}$ \\
\hline Adjusted $\mathrm{R}^{2}$ & 0.992 & 0.944 & 0.956 \\
\hline Durbin-Watson & 1.90 & 1.24 & 1.88 \\
\hline $\begin{array}{l}\text { Number of } \\
\text { observations }\end{array}$ & 39 & 39 & 39 \\
\hline $\begin{array}{l}\text { Instrumental } \\
\text { Variables }\end{array}$ & $\begin{array}{l}\mathrm{C}(-2), \mathrm{Y}(-1), \mathrm{M}(-1), \\
\mathrm{R}, \mathrm{G}, \mathrm{D} 1974, \mathrm{D} 2001\end{array}$ & $\begin{array}{l}\mathrm{C}(-1), \mathrm{C}(-2), \mathrm{Y}(-1), \mathrm{Y}(-2), \\
\mathrm{G}(-1), \mathrm{G}(-2), \mathrm{E}(-1), \mathrm{E}(-2), \\
\mathrm{D} 1974, \mathrm{D} 2001\end{array}$ & $\begin{array}{l}\mathrm{C}(-1), \mathrm{Y}(-1), \mathrm{Y}(-2), \\
\mathrm{G}, \mathrm{G}(-1), \mathrm{M}(-2), \\
\mathrm{I}(-1), \text { DTotal }\end{array}$ \\
\hline
\end{tabular}

Notes: Absolute values of the t-ratios are given in parentheses. 
Table 1 presents the estimation results of the model. The equations also include dummy variables defined as follows. D1974 takes the value of one in 1974 just after the first oil shock in 1973 and zero otherwise. D2001 takes the value of one in 2001 corresponding to the financial crisis in Turkey and zero otherwise. DTotal takes the value of one in 1974 just after the first oil shock in 1973, in 1978 debt crisis, in 1980, 1981, 1982 corresponding to the transition period of Turkey and in 1994 and 2001 corresponding to the economic crises in Turkey and zero otherwise. There is the possibility of a structural break at or near 24 January 1980. At that date, strict foreign exchange controls that were in place since the 1930's were lifted and the Turkish lira was made convertible. In the pre-1980 period it was common practise for businessmen (who were allocated less foreign exchange by the state than they desired) to buy the remittances of the Turkish workers abroad (at the market rate rather than the lower official rate) and make the payment to their families in Turkey in liras. They would then declare to the state a lower price for their imports than what they actually paid. Thus during this period, remittances and import price indices were under-reported and the value of real imports were over-reported. It would be ideal to enter into the model a variable measuring the difference between the official and the black market rates of German Mark or U.S. dollar (interacting with other relevant variables). However the data is not available. We have experimented with various specifications of the dummy variables. Only Dtotal which included the period of 1980 was statistically significant in the import equation, indicating that the periods before and after 1980 were different only for imports.

All of the coefficient estimates except that of the lagged capital stock are statistically significant with theoretically expected signs. The short-run Marginal Propensity to Consume (MPC) is 0.35. Similar estimates are found by Glytsos (2002b). He found that the MPC estimates are between 0.32-0.39 for Egypt, Greece and Portugal and 0.24 for Jordan. Marginal 
Propensity to Invest is estimated as 0.33 for Turkey. Glytsos found it to be between $0.13-0.39$ for all of the above countries except Egypt. The marginal propensity to import (MPI) for Turkey is estimated as 0.16 . Glytsos found it to be between $0.14-0.40$ except for Morocco with the highest value belonging to Jordan. Using the estimates in Table 1, the long-run MPC is estimated to be 0.612 and the long-run MPI is estimated to be 0.518 . As expected the longrun values are higher than the corresponding short-run values. Further, the short-run MPC is larger than the short-run MPI while the long-run MPC and the MPI are about the same. These results indicate that consumption is more responsive in the short-run to the changes in income than imports while their long-run responsiveness are about the same.

Table 2. Impact and Dynamic Multipliers for the Effect of a Unit Change in Remittances.

\begin{tabular}{|l|c|c|c|c|}
\hline & $\begin{array}{c}\text { Impact } \\
\text { Multipliers }\end{array}$ & \multicolumn{3}{|c|}{ Dynamic Multipliers } \\
\cline { 2 - 5 } & Year 1 & Year 2 & Year 3 & Year 4 \\
\hline Consumption & $\alpha_{1} / \mathrm{A}$ & $\mathrm{P}\left(\alpha_{1} / \mathrm{A}\right)$ & $\mathrm{P}^{2}\left(\alpha_{1} / \mathrm{A}\right)$ & $\mathrm{P}^{3}\left(\alpha_{1} / \mathrm{A}\right.$ \\
\hline Investment & $\beta_{1} / \mathrm{A}$ & $\mathrm{M}\left(\beta_{1} / \mathrm{A}\right)$ & $\mathrm{M}^{2}\left(\beta_{1} / \mathrm{A}\right)$ & $\mathrm{M}^{3}\left(\beta_{1} / \mathrm{A}\right)$ \\
\hline Imports & $\delta_{1} / \mathrm{A}$ & $\mathrm{N}\left(\delta_{1} / \mathrm{A}\right)$ & $\left.\mathrm{N}^{2} \delta_{1} / \mathrm{A}\right)$ & $\mathrm{N}^{3}\left(\delta_{1} / \mathrm{A}\right)$ \\
\hline Income & $\left(\left(\alpha_{1}+\beta_{1}-\delta_{1}\right) / \mathrm{A}\right)+1$ & $\mathrm{See}$ text & See text & See text \\
\hline & $\mathrm{A}=1-\beta_{1}-\alpha_{1}+\delta_{1}$ & $\mathrm{M}=\beta_{2}\left(1-\alpha_{1}+\delta_{1}\right) / \mathrm{A}$ & $\mathrm{N}=\delta_{2}\left(1-\alpha_{1}-\beta_{1}\right) / \mathrm{A}$ & $\mathrm{P}=\alpha_{2}\left(1-\beta_{1}+\delta_{1}\right) / \mathrm{A}$ \\
\hline
\end{tabular}

The Reduced Form equations express the endogenous variables as a function of all of the predetermined variables in the model. They can be used to find the short-run or impact multipliers. Further, it is useful to determine the dynamic effects of the shocks in the exogenous variables on the endogenous variables. The dynamic or interim multipliers can be derived from the Final Form equations for the endogenous variables which are obtained by making continuous substitions for the dynamic terms (Intriligator et al., 1996). The formulas 
for the impact and the dynamic multipliers are provided in Table 2 and their estimates are given in Table $3^{5}$.

Table 3. Time Distribution of the Effects of a Unit Change in Remittances on Endogenous Variables. (Impact and Dynamic Multipliers).

\begin{tabular}{|l|l|l|l|l|}
\hline & Impact Multipliers & \multicolumn{3}{|c|}{ Dynamic Multipliers } \\
\hline & Year 1 & Year 2 & Year 3 & Year 4 \\
\hline Consumption & 0.728 & 0.538 & 0.398 & 0.294 \\
\hline Investment & 0.684 & -0.0023 & 0.000008 & -0.00000003 \\
\hline Imports & 0.333 & 0.153 & 0.071 & 0.033 \\
\hline Income & 2.079 & 0.383 & 0.327 & 0.261 \\
\hline
\end{tabular}

The dynamic multipliers for income are obtained by adding the multipliers for consumption and investment and subtracting that for imports. The dynamic multipliers give the effect of a unit change in remittances in year 1 with no further increase in the subsequent years all other predetermined variables remaining unchanged ${ }^{6}$. The results indicate that the impact of remittances on consumption, investment, imports and income are all positive both in the short and the long-run. The dynamic multipliers are smaller than the impact multipliers. The impact of remittances on investment wears out in the second year while that on consumption reduces only gradually. This may be explained with the Permanent Income Hypothesis which emphasizes the importance of life-time income in spending distributed over time. Glytsos (2002b) finds that the effect of remittances on investment wears out in the first or the second year in all of Egypt, Greece, Jordan, Morocco and Portugal.

The impact multiplier for investment is close to that of consumption while its dynamic multipliers are essentially zero. The impact and dynamic multipliers for imports are much

\footnotetext{
${ }^{5}$ The dynamic (interim) multipliers are calculated for 3 years, since the dynamic multipliers for investment converges to zero in 3 years.

${ }^{6}$ For details see Intriligator et al. (1996: 31).
} 
smaller than that of consumption. The changes in consumption investment and imports brought about by remittances are reflected in changes in income. The impact multiplier for income is substantial. This is similar to the impact multiplier for income obtained for Greece by Glytsos (2002a). The multipliers imply that a $1000 \mathrm{TL}$ increase in remittances leads to a 2079 TL increase in income in year 1, 382 TL in year 2, 327 TL in year 3 and 262 TL in year 4, through the multiplier effects.

Figure 2. Rates of Output (GDP) Growth Induced by Remittances and Overall Actual Rates of Output (GDP)Growth, 1968-2003.

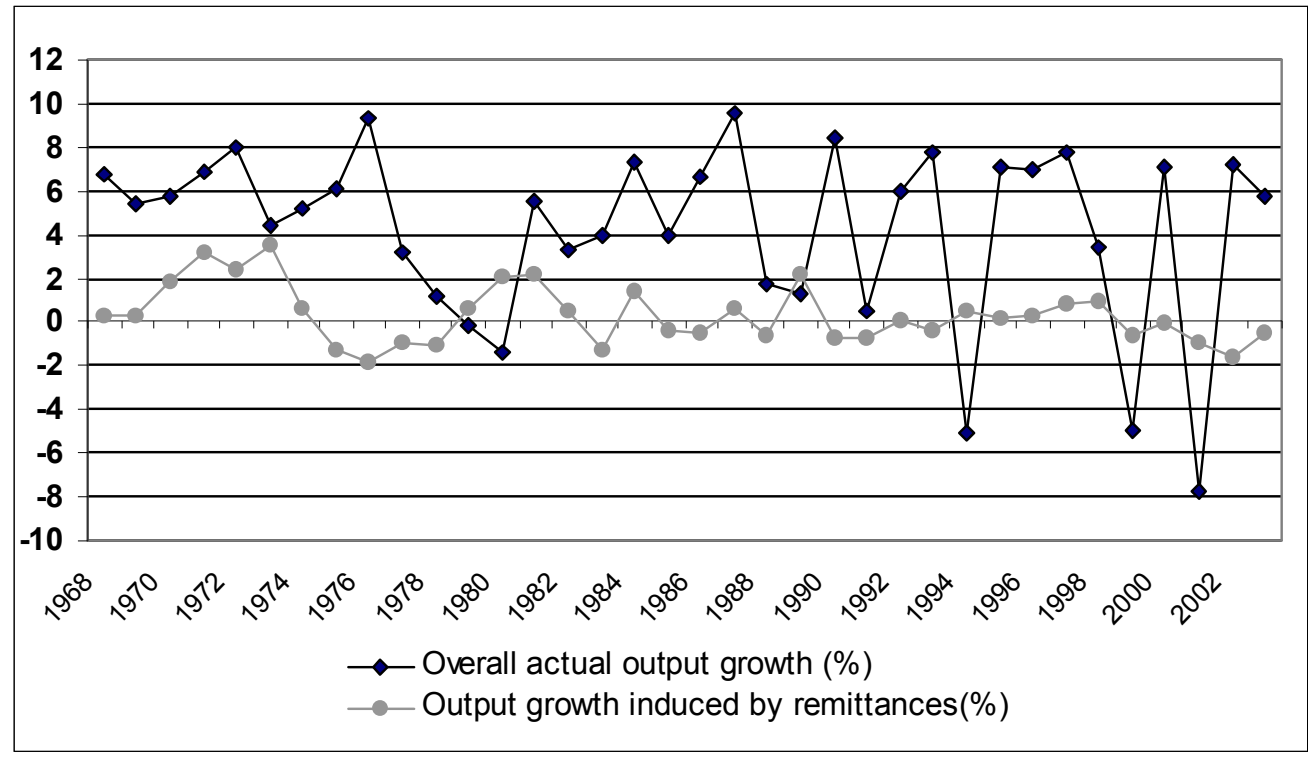

Finally, in this section the impact of a change in remittances on current and future growth rates of output are presented. The estimated impact and dynamic multipliers are used for a four-year time distribution of the effect of remittances on output growth. Following formula is applied:

$$
\Delta \mathrm{Y}_{\mathrm{t}}=\frac{\partial Y_{t}}{\partial R_{t}} * d R_{t}+\frac{\partial Y_{t}}{\partial R_{t-1}} * d R_{t-1}+\frac{\partial Y_{t}}{\partial R_{t-2}} * d R_{t-2}+\frac{\partial Y_{t}}{\partial R_{t-3}} * d R_{t-3}
$$


Figure 3 presents the results of this computation for the period 1968-2003 together with the actual growth rates ${ }^{7}$. Remittances appear to contribute to output growth through the multiplier effects in most of the years. The highest induced growth rate occurs in 1973 which coincides with the first oil shock. For the period 1970-73 the remittances-induced growth rate is 2.7 percent on average ${ }^{8}$. During this period the remittances contributed to the financing of imports of machinery and other intermediate goods increasing domestic output (Russell, 1992: 274). After the 1973 first oil shock, most of the Western European countries restricted labor recruitment which led to a decline in remittance flows. In the early 1980's the induced growth rates are again relatively high. For instance, for this period the remittances-induced growth rates are 1.6 percent. This is due to the increase in remittance flows with the onset of Turkish migration to the Middle East and North African countries in the early 1980's. For the other periods, the remittances-induced growth rates are either positive or negative and range between 0.5-2.0 percent demonstrating moderate effects in either direction with declining importance of the remittances in the later years. Glytsos (2002b) also found negative induced growth rates in some years in Egypt and Jordan where the overall contribution of the remittances to growth is noteworthy. In Morocco, Greece and Portugal remittances-induced growth rates are observed to take positive as well as negative values but they were very weak in general.

\footnotetext{
${ }^{7}$ It is more useful to look at the impact of a change in the remittances in the current period on the future values of the endogenous variable (Stewart and Gill, 1998: 184-185).

${ }^{8}$ Following the devaluation in 1970, like workers' remittances, exports increased significantly. Turkish exports, were 588 million dollars in 1970 and increased to 1.3 billion dollars in 1973. Thus, in the early 1970s, the contribution of exports to growth is noteworthy.
} 


\section{Conclusions}

To our knowledge this is the first study on the macroeconomic impact of the remittances on the Turkish economy in a unified framework. For this purpose a demandoriented, dynamic, simultaneous equation macroeconometric model for the Turkish economy for the period 1964-2003 is estimated with TSLS estimation method. This model was used successfully to measure these impacts in several countries near Turkey or with similar characteristics to Turkey, such as Egypt Greece, Jordan, Morocco and Portugal. The aim is to analyze the impact of remittances on the key macroeconomic variables. First, the estimates of the consumption, investment and imports equations yielded the marginal propensity to consume (MPC) and marginal propensity to import (MPI) for the short-run and the long-run. Second the impact and dynamic multipliers of a unit change in the remittances on consumption, investment, imports and income are evaluated. Finally, the results are used to evaluate the impact of remittances on current and future growth rates of output with a fouryear time distribution of the remittance effect.

The estimated size of the MPC and MPI are reasonable and comparable to those of the other countries. The estimates for the impact and dynamic multipliers indicate that the impact of remittances on consumption, investment, imports and income are all positive. The impact of remittances on consumption, imports and income reduces gradually while that on investment wears out in the second year. The impact of a change in remittances on consumption lasts several years may be explained with the Permanent Income Hypothesis which emphasizes the importance of life-time income in spending. The impact and dynamic multipliers for imports are much smaller than that of consumption. The impact multiplier for income is 2.079 which implies a substantial increase in income due to remittances through the 
multiplier process. It is noteworthy that the remittances-induced output growth rate was mostly positive throughout the period 1968-2003. The highest remittances-induced output growth occurred in the early 1970's in particular in 1973 which is the year of the first oil shock, corresponding to the period when the share of remittances in GDP and imports was the highest. During this period, the remittances financed the imports of machinery and other intermediate goods increasing domestic production. In the second half of the 1970's, following the labor recruitment ban in Europe the amount of remittances declined dramatically and the remittances-induced output growth rates were either very small or negative. In the early 1980s, the Turkish migration to Middle Eastern and North African countries led to an increase in the remittance flows. For this period the remittances-induced output growth rates were high again. In the 1990s and the early 2000s, although the absolute level of remittances continued to increase, their share in GDP and their relative importance in the Turkish economy declined. During this period their contribution to output growth was negligible. Overall, evidence provided in this study indicates that the remittances have been a positive factor in the development and growth of Turkey. The findings of this paper have important implications or possible uses in policy making or in making predictions. For instance, while examining the effect of a crisis in Europe on the domestic economy we must consider that not only exports and remittances may be affected, but consumption and investment may also be affected indirectly through remittances. Therefore, the results indicate that while making projections or predictions of consumption and investment they could be made more accurate by taking the effect of remittances into account. These results may be useful to planners and policy makers. 


\section{Appendix: Data Sources}

The data of workers' remittances ${ }^{\circledR}$ are obtained for the period 1964-2003 from the State Planning Organization (SPO) (2003). The data is given in millions of current US Dollars. For the same period, average exchange rates are received from the website of the Central Bank of Turkey (Electronic Data Delivery System). The official Consumer Price Index is obtained from the OECD (2008) Economic Outlook database. First, by using average exchange rates, workers' remittances are converted into billions of Turkish Lira (TL). Then, they are deflated by the Consumer Price Index (base 1987). Thus, real workers' remittances in terms of billions of TL are obtained. The data for Private Final Consumption Expenditures (C), Government Final Consumption Expenditures (G), Gross Fixed Capital Formation (I), Exports of Goods and Services (E), Imports of Goods and Services (I), Gross Domestic Product (GDP) and Statistical Discrepancy (SD) are all at constant 1987 prices in terms of TL for the period of 1964-2003 and are obtained from the OECD (2008) Economic Outlook database. As a proxy to capital stock, the cumulative gross fixed capital formation is used. The level of Income (Y) is derived as the sum of GDP and workers' remittances $(\mathrm{R})$. 


\section{REFERENCES}

Abadan-Unat, N., R, Keleş, R. Pennix, H.van Renselaar, L.van Velzen and L.Yenisey (Eds.). (1975). Göç ve Gelişme: İşgücü Göçünün Boğazlıyan İlçesindeki Etkilerine İlişkin Bir Araştırma (Migration and Development: A study about the Effects of Labour Migration on Boğazlıyan District), Ankara: Ajans-Türk Matbaası.

Acosta, P. A., (2006). "Labor Supply, School Attendance and Remittances from International Migration: The Case of El Salvador," Washington, D.C.: World Bank Policy research Working Paper No. 3903.

Acosta, P. A., E. K. K. Lartey, and F. Mandelman (2007). "Remittances and Dutch Disease", FRB of Atlanta Working Paper, No. 2007-8.

Adams, R. and J. Page (2005). "Do International Migration and Remittances reduce Poverty in Developing Countries?" World Development, 33: 1645-1669.

Aggarwal, R., A. Demirguc-Kunt, and M. S. M. Peria (2006). "Do Workers' Remittances

Promote Financial Development?" Washington, D.C.: World Bank Policy Research Working Paper, No. 3957.

Athukorala, P. (1993). "International Labor Migration in the Asia-Pacific Region: Patterns, Policies and Economic Implications," Asian-Pacific Economic Literature, 7: 2857.

Aydaş, O.T., B. Neyapti and K. Metin-Özcan (2005). "Determinants of Workers' Remittances: The Case of Turkey," Emerging Markets Finance and Trade, 41(3): 53-69.

Boratav, K. (2003). Türkiye İktisat Tarihi: 1908-2002 (Turkish Economic History:19082002), Ankara: İmge Kitapevi Publication, Seventh Edition. 
Bourdet, Y. and H. Falck (2003). "Emigrants' Remittances and Dutch Disease in Cape Verde," Lund, Sweden: Lund University Department of Economics Working Paper 2003:11.

Burgess, R. and V. Haksar (2005). "Migration and Foreign Remittances in the Philippines," Washington, D.C.: IMF Working Paper No. 05/111.

Catrinescu, N., M. Leon-Ledesma, M. Piracha and B. Quillin (2006). "Remittances, Institutions and Economic Growth," Bonn, Germany: Institute for the Study of Labor (IZA) Discussion Paper No. 2139.

Chami, R., C. Fullenkamp, and S. Jahjah (2003). "Are Immigrant Remittance Flows a Source of Capital for Development?” Washington, D.C.: IMF Working Paper No. 03/189.

Faini, R. (2002) "Migration, Remittances and Growth," Paper presented at UNUWIDER conference on Poverty, International Migration and Asylum, 27-28 September. Helsinki: UNU-WIDER.

Gitmez, A. (1991) "Migration without Development: The case of Turkey," in Papademetriou, D.G. and Martin, P. (eds.) The Unsettled Relationship: Labour Migration and Economic Development, New York: Contributions in Labour Studies, No. 33, Greenwood Press, pp.115-134.

Glytsos, N. P. (1993). "Measuring the Income Effects of Migrant Remittances: A Methodological Approach Applied to Greece”, Economic Development and Cultural Change, 42: 131-168.

Glytsos, N. P. (2002a). "A Macroeconometric Model of the Effects of Migrant Remittances in Mediterranean Countries," in İ.S1rageldin (ed.), Human Capital Population Economics in the Middle East, Cairo, Egypt: An Economic Research Forum Edition, The American University in Cairo Press, pp. 300-325. 
Glytsos, N. P. (2002b). "Dynamic Effects of Migrant Remittances on Growth: An Econometric Model with an Application to Mediterranean Countries," Discussion Paper, No. 74 0505014, Labor and Demography, Economics Working Paper Archive at Washington University in St.Louis.

Glytsos, N. P. (2002c). “A Model of Remittance Determination Applied to Middle East and North Africa Countries", Discussion Paper, No. 73 0505016, Labor and Demography, Economics Working Paper Archive at Washington University in St.Louis.

Gökdere, A.Y. (1978). Yabancı Ülkelere Isşgücü Akımı ve Türk Ekonomisi Üzerine Etkileri, (Labour Flows to Foreign Countires and Its Impact on the Turkish Economy), Ankara: Türkiye İş Bankası Kültür Publications:196.

Guilano, P. and M. Ruiz-Arranz (2005). "Remittances, Financial Development, and Growth," Washington, D.C.: IMF Working Paper No. 05/234.

Gupta, P. (2005). "Macroeconomic Determinants of Remittances: Evidence from India," Washington, D.C.: IMF Working Paper No. 05/224.

İçduygu, A. (2006). "International Migrants Remittances in Turkey," Florence, Italy: CARIM Research Reports, No. 07, European University Institute.

Intriligator, M. D., R. Bodkin and C. Hsiao (1996). Econometric Models, Techniques and Applications, Second Edition, New Jersey: Prentice- Hall.

Kapur, D. (2004). "Remittances: The New Development Mantra?” New York: Discussion Paper Series, No. 29, G-24, United Nations.

Keely, C. B, Tran, B. N. (1989). "Remittances from Labour Migration: Evaluations, Performance and Implications," International Migration Review, 23(3): 500-525.

Koç, İ. and I. Onan (2004). “International Migrants' Remittances and Welfare Status of the Left-Behind Families in Turkey," International Migration Review, 38(1): 78-112. 
Lean-Ledesma, M. and M. Piracha (2001). "International Migration and the Role of Remittances in Eastern Europe," Kent, UK: Department of Economics, University of Kent at Canterbury Discussion Paper No. 1/ 13.

Lucas, R. E. B. (2004). "International Migration to the High Income Countries: Some Consequences for Economic Development in the Sending Countries," Brussels, Belgium: Paper prepared for the Annual Bank Conference on Development Economics, 10-11 May.

Martin, P. (1991). The Unfinished Story: Turkish Labour Migration to Western Europe, Geneva: International Labour Organization.

Mishra, P. (2005). "Macroeconomic Impact of Remittances in the Caribbean," unpublished. Washington, D.C.: International Monetary Fund.

Mouhoud E.M, J. Oudinet and E. Unan (2006). "Migration and Remittances in the Mediterranean Basin: The Case of Turkey,” Paris, France: Working Paper, CEPN-CNRS, No. 2006-10. Centre d'Economie de l'Universite de Paris Nord.

Paine, S. (1974). Exporting Workers: The Turkish Case, London: Cambridge University Press.

Quartey P. (2005). "Shared Growth in Ghana: Do Migrant Remittances Have a Role?" Cornell/ ISSER/ World Bank International Conference on Shared Growth in Africa, Acra, Ghana.

Quibria, M. G. (1996). "Migration, Remittances and Trade: With Special Reference to Asian Developing Economies." in P.J. Lloyd and S. Williams (Eds), International Trade and Migration in the APEC Region, Melbourne: Oxford University Press, pp. 84-98.

Ratha, D. (2003). "Workers Remittances: an Important and Stable Source of External Development Finance," Global Development Finance, Washington, D.C.: The World Bank, pp.157-175. 
Russell, S. (1992). "Migrant Remittances and Development" International Migration: Quarterly Review 30 (3/4): 267-287.

Saca, S. S and L. R. Cáceres (2006). "What Do Remittances Do? Analyzing the Private Remittance Transmission Mechanism in El Salvador," Washington, D.C.: IMF Working Paper, No. 06/250.

Sayan, S. (2004). “Guest Workers' Remittances and Output Fluctuations in Host and Home Countries: The Case of Remittances from Turkish Workers," Emerging Markets Finance and Trade, 40 (6): 68-81.

Schiopu, I. and N. Siegfried (2006). "Determinants of Workers' Remittances Evidence From the European Neighbouring Region,” Frankfurt, Germany: European Central Bank Working Paper, No. 688.

Stahl, C and A. Habib (1991). "Emigration and Development in South and Southeast Asia," in Papademetriou, D.G. and Martin, P. (eds.): The Unsettled Relationship: Labour Migration and Economic Development, Westport: Contributions in Labour Studies, No. 33, Greenwood Press.

State Planning Organization (SPO) (2003). Economic and Social Indicators (1950-2003), Ankara: SPO.

Statistical Institute of Turkey (TURKSTAT) (2002). Statistical Yearbook of Turkey, Ankara: TURKSTAT.

Stewart, J and L.Gill (1998). Econometrics, Second Edition, Hempstead: Prentice Hall.

Turkish Labor Office, (2001). İstatistik Yıllı̆̆ (Statistical Yearbook), Ankara: Çalışma ve Sosyal Güvenlik Bakanlığı, Türkiye İş Kurumu Genel Müdürlüğü.

World Bank (2006). Global Economic Prospects: Economic Implications of Remittances and Migration. Washington, D.C.: The World Bank Report No. 34320. 
Yiğit, F. P. E. (2005). "İsçi Gelirleri ve Büyümedeki Çevrimler Arasındaki İlişki" (Relation Between Cycles in Workers' Remittances and Growth Cycles), Ankara: Specialization Thesis, TCMB İsçi Dövizleri Genel Müdürlügü. 